\title{
ILLEGAL FISHING IKAN TUNA DAN TONGKOL DI ZONA EKONOMI EKSKLUSIF INDONESIA
}

\author{
*(Abid Muhtarom, Nurul Badriyah, Uzlifatul Masruroh Isnawati \\ Fakultas Ekonomi \\ Universitas Islam Lamongan
}

\begin{abstract}
ABSTRAK
Indonesia merupakan salah satu negara yang memiliki banyak pantai mengingat status Indonesia sebagai negara kepulauan. Hal ini tentu saja mengakibatkan Indonesia juga terkena masalah illegal fishing. Menurut Jurnal "The use of trade measures against illicit fishing: Economic and legal considerations" menjelaskan penangkapan ikan merupakan ancaman bagi kelautan lingkungan dan masyarakat. Dengan merusak sistem manajemen yang efektif, IUU fishing mempengaruhi kinerja ekonomi, kesejahteraan sosial dan keputusan kepatuhan, (Gallic, 2007).

Penelitian ini mengunakan metodologi kualitatif dengan proposive sampling. dengan lokasi penelitian di perairan seluruh Indonesia. sumber data primer dan sekunder. Data yang diperoleh dari sumber internet.

Pemberantasan pencurian ikan di perairan Indonesia berdampak langsung pada anjloknya ekspor perikanan Thailand yang berimbas kepada produk domestik bruto (PDB) negara tersebut. Data National Economic and Social Development Board (NESDB) Thailand mengungkapkan kontribusi sektor perikanan terhadap $P D B$ Thailand mengalami penurunan drastis. Kontribusi rata-rata sektor perikanan terhadap GDP Thailand selama ini tercatat sebesar 1,6 persen, sedangkan di kuartal III 2015 kontribusinya minus 3,1 persen. Sementara Kementerian Kelautan dan Perikanan (KKP) mencatat pada 2013 sampai kuartal II 2014, industri perikanan Thailand mengalami penurunan. Kemudian mulai membaik dari pertengahan kuartal III sampai pertengahan kuartal IV. Namun sejak itu, industri perikanan Thailand terus menurun hingga saat ini.Salah satu penyebab utamanya adalah kebijakan Menteri Kelautan dan Perikanan Susi Pudjiastuti yang mulai memberantas kapal penangkap ikan ilegal dan moratorium bekas kapal asing di kuartal IV 2014. Selain sebagai kejahatan perikanan, Susi juga ingin mendorong Illegal, Unreported, and Unregulated (IUU) Fishing sebagai permasalahan global dan memiliki sifat kejahatan transnasional. Salah satu alasan Susi ingin mengecam lebih luas penangkapan pencuri ikan karena kejahatan ini kerap memfasilitasi pelanggaran lainnya, seperti perdagangan satwa liar, perdagangan senjata, penyelundupan narkoba dan perbudakan.
\end{abstract}

Kata Kunci: Illegal Fishing, Komoditi Tuna dan Tongkol, ZEE.

LATAR BELAKANG Masalah Ilegal fishing

Illegal fishing merupakan masalah klasik yang sering dihadapi oleh negara yang memiliki banyak pantai karena masalah tersebut sudah ada sejak dulu.Namun hingga sekarang 
masalah illegal fishing masih belum dapat diberantas.Hal itu dikarenakan untuk mengawasi wilayah laut yang banyak secara bersamaan itu merupakan hal yang sulit.Negara yang sudah memiliki teknologi yang maju dibidang pertahanan dan keamanan sekalipun pasti juga pernah terkena kejahatan illegal fishing.

Indonesia merupakan salah satu negara yang memiliki banyak pantai mengingat status Indonesia sebagai negara kepulauan. Hal ini tentu saja mengakibatkan Indonesia juga terkena masalah illegal fishing. Adapun daerah yang menjadi titik rawantersebut terletak di Laut Arafuru, Laut Natuna, sebelah Utara Sulawesi Utara (Samudra Pasifik), Selat Makassar, dan Barat Sumatera (Samudera Hindia).

Menurut Jurnal "The use of trade measures against illicit fishing: Economic and legal considerations" menjelaskan penangkapan ikan merupakan ancaman bagi kelautan lingkungan dan masyarakat. Dengan merusak sistem manajemen yang efektif, IUU fishing mempengaruhi kinerja ekonomi, kesejahteraan sosial dan keputusan kepatuhan. (Gallic, 2007)

Banyak faktor yang menyebabkan terjadinya illegal fishing di ZEE Indonesia. Salah satunya yaitu celah hukum yang terdapat dalam ketentuan Pasal 29 Undang-Undang No. 31 Tahun 2004 tentang Perikanan. Dalam ketentuan Pasal 29 ayat (2) Undang-Undang No. 31 Tahun 2004 tentang Perikanan disebutkan bahwa orang atau badan hukum asing itu dapat masuk ke wilayah ZEE Indonesia untuk melakukan usaha penangkapan ikan berdasarkan persetujuan internasional atau ketentuan hukum internasional yang berlaku. Ketentuan Pasal 29 ayat (2) Undang-Undang No. 31 Tahun 2004 tentang Perikanan seakan membuka jalan bagi nelayan atau badan hukum asing untuk masuk ke ZEE Indonesia untuk kemudian mengeksplorasi serta mengeksploitasi kekayaan hayati di wilayah ZEEIndonesia.

Tuna merupakan salah satu jenis ikan tangkap yang paling banyak diburu oleh berbagai negara.Alasannya karena ikan ini memiliki tingkat protein yang cukup tinggi dengan harga jual yang lumayan mahal. Indonesia patut bangga karena mayoritas jenis tuna yang ada di dunia ada di sini.Itu tidak terlepas dari posisi geografis Indonesia yang strategis yaitu terletak antara dua samudera yaitu Samudera Hindia dan Samudera Pasifik.

Tidak hanya di Indonesia, penyebaran ikan tuna juga ada di beberapa negara mulai dari Laut Merah, Laut India, dan Malaysia.Ikan tuna juga terdapat di laut daerah tropis dan daerah beriklim sedang.Namun KKP menegaskan, penyebaran terbesar ikan tuna di dunia ada di Indonesia. Namun hal itu tidak dapat disalahkan karena merupakan salah satu bentuk penerapan aturan yang telah ditentukan dalam Konvensi Hukum Laut Tahun 1982 yang merupakan salah satu konvensi internasional yang telah diratifikasi oleh Indonesia melalui UndangUndang No. 17 Tahun 1985.

Dalam ketentuan Pasal 62 
ayat (3) dan (4) Konvensi Hukum Laut Tahun 1982 mengharuskan negara pantai untuk memberikan hak akses kepada negara lain untuk mengeksploitasi kekayaan hayati di wilayah ZEE negara pantai apabila terjadi surplus dalam hal pemanfaatan sumber daya hayati oleh negara pantai. Kapal-kapal ikan asing yang mempunyai hak akses pada zona ekonomi eksklusif suatu negara pantai harus menaati peraturan perundang-undangan negara pantai yang bersangkutan, yang dapat berisikan kewajibankewajiban dan persyaratanpersyaratan mengenai berbagai macam hal, seperti perizinan, imbalan keuangan, kuota, tindakan-tindakan konservasi, informasi, riset, peninjau, pendaratan tangkapan, persetujuanpersetujuan kerja sama, dan lain sebagainya.

Ikan tuna menjadi incaran utama para maling ikan di laut Indonesia, alasannya jenis ikan ini punya nilai ekonomis yang tinggi. Di pasar internasional harga satu ekor ikan tuna bisa mencapai Rp 1 miliar.

"Ikan tuna ini memiliki posisi strategis, punya harga nilai tinggi bahkan internasional, dan ekonomis.Jadi punya nilai dia," ungkap Ketua Asosiasi Tuna Indonesia (Astuin) Edi Yuwono" kepada detikFinance, Selasa (8/07/2014).

Indonesia sebagai anggota Komisi Tuna Samudra Hindia atau Indian Ocean Tuna Convention (IOTC) dan anggota Komisi Tuna Samudera Pasifik atau West and Central Pacific Fisheries Convention (WCPFC) memberlakukan kuota penangkapan ikan tuna karena harga ikan jenis ini bisa miliaran rupiah.

Menurut data KKP yang dikutip dari IOTC, setiap tahun ada 900.000 ton tuna sirip kuning, tuna mata besar, cakalang, dan madidihang ditangkap dari perairan Samudra Hindia. Penangkapan tuna sirip kuning setiap tahun mencapai 435.000 ton, mendekati ambang batas tangkapan. Adapun penangkapan cakalang setiap tahun 514.000 ton.

Ada 16 jenis ikan tuna yang diatur pengelolaannya oleh IOTC, antara lain tuna sirip kuning, sirip biru, cakalang, tuna mata besar, madidihang, tongkol, black marlin, swordfish, kawakawa, frigate tuna, bullet tuna, strip marlin, dan narrow barred spanish. Kasus illegal fishing sampai sekarang belum terselesaikan disebabkan juga karena belum maksimalnya upaya yang dilakukan oleh Indonesia dalam menangani masalah illegal fishing di ZEE Indonesia.

\section{PEMBAHASAN \\ Kegiatan Illegal Fishing}

Kementerian Kelautan dan Perikanan (KKP) bakal mengeluarkan aturan tentang pengendalian penangkapan untuk ikan tuna dan ikan tongkol di sejumlah kawasan penangkapan ikan di perairan Republik Indonesia.Indonesia memegang peranan penting dalam kerja sama tuna regional, mengingat posisi wilayah Indonesia yang berada di antara dua samudra, samudra Pasifik dan Hindia. Dua samudra yang menghubungkan perairan di teritorial Indonesia dan kepulauan menjadikan laut Indonesia kaya dengan tuna. 


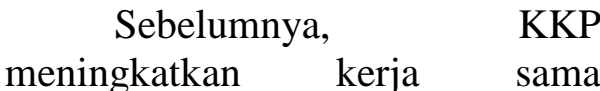
internasional dalam mengatasi kejahatan kemanusiaan terutama di sektor kelautan seperti adanya perdagangan barang ilegal, hewan langka, hingga perdagangan manusia. KKP menjalin kerja sama dalam melindungi kawasan kelautan antara lain dengan sejumlah lembaga internasional di bawah naungan PBB seperti Organisasi Internasional untuk Migrasi (IOM) dan Organisasi Buruh Internasional (ILO).

Sementara dengan ILO ingin KKP melakukan peningkatan perlindungan terhadap tenaga kerja perikanan Indonesia melalui dorongan ratifikasi Konvensi ILO No.188, tentang dukungan terhadap penyusunan dan penyebaran Peraturan Menteri Kelautan dan Perikanan tentang perlindungan HAM.

Illegal fishing atau penangkapan ikan secara ilegal menurut International Plan of Action-Illegal, Unreported and Unregulated Fishing (IPOA-IUU Fishing) adalah kegiatan penangkapan ikan yang dilakukan oleh suatu negara tertentu atau kapal asing di perairan yang bukan merupakan yuridiksinya tanpa izin dari negara yang memiliki yuridiksi atau kegiatan penangkapan ikan tersebut bertentangan dengan hukum dan peraturan negara itu (Activities conducted by national or foreign vessels in waters under the jurisdiction of a state, without permission of that state, or in contravention of its laws and regulation).
Kegiatan Illegal Fishing yang umum terjadi di perairan Indonesia adalah:

a. Penangkapan ikan tanpaizin;

b. Penangkapan ikan dengan mengunakan izinpalsu;

c. Penangkapan ikan dengan menggunakan alat tangkapterlarang;

d. Penangkapan ikan dengan jenis (spesies) yang tidak sesuai dengan Izin.

Penyebab Illegal Fishing:

a. Meningkat dan tingginya permintaan ikan(DN/LN)

b. Berkurang/habisnya Sumber Daya Ikan (SDI) di Negara lain

c. Lemahnya armada perikanan nasional

d. Izin/dokumen pendukung dikeluarkan lebih dari satu instansi

e. Lemahnya pengawasan dan penegakan hukum dilaut

f. Lemahnya delik tuntutan dan putusan pengadilan

g. Belum ada visi yang sama aparat penegakhokum

h. Lemahnya peraturan perundangan dan ketentuan pidana

Dampak kegiatan IUU Fishing bagi Indonesia sebagaiberikut:

a. Ancaman terhadap kelestarian sumber dayaikan;

b. Terdesaknya mata pencaharian masyarakat nelayan lokal dengan armada penangkapan skala kecil dan alat tangkap sederhana, karena kalah bersaing dengan pelaku illegalfishing;

c. Hilangnya sebagian produksi ikan dan peluang perolehan 
devisa negara;

d. Berkurangnya Penerimaan Negara Bukan Pajak (PNBP);

e. Terhambatnya upaya Indonesia untuk memperkuat industri pengolahan ikan di dalam negeri, termasuk meningkatkan daya saing;

f. Merusak citra Indonesia pada kancah internasional, karena kapal asing yang menggunakan bendera Indonesia maupun kapal milik warga negara Indonesia melakukan kegiatan penangkapan ikan secara ilegal yang bertentangan dengan konvensi dan kesepakatan internasional. Hal ini juga dapat berdampak ancaman embargo terhadap hasil perikanan Indonesia yang dipasarkan di luarnegeri.

Namun kegiatan illegal fising juga mengalami hambatanhambatan dari factor luar pemerintahan salah satunya dari jurnal "Motivasi, Sikap, Dan Intensi Pengguna Media Sosial Pada Kampanye Stop Illegal Fishing" Menjelaskan Media Sosial Sering Digunakan untuk mempromosikan kampanye sosial, contohnya adalah kampanye Stop Illegal Fishing. Untuk meraih kesuksesan pada kampanye ini, beberapa hal yang harus diraih adalah sikap positif pengguna media sosial terhadap kampanye dan intensi yang tinggi untuk memberikan rekomendasi (word of mouth) kepada orang lain. Penelitian ini dilakukan untuk menganalisis motivasi pengguna apa saja yang memengaruhi sikap pengguna media sosial terhadap kampanye sosial (stop illegal fishing) di media sosial. Selain itu menganalisis sikap pengguna berpengaruh pada intensi pengguna untuk melakukan WOM.

Metode yang digunakan untuk menjawab tujuan adalah dengan metode Partial Least Square. Hasil penelitian menunjukkan motivasi pengguna untuk menggunakan media sosial dan terhadap pesan kampanye terbukti secara signifikan berpengaruh positif pada sikap pengguna terhadap kampanye sosial di media sosial. Selain itu peningkatan intensi untuk memberi WOM dipengaruhi secara positif oleh sikap pengguna media sosial. Terdapat perbedaan motivasi yang memengaruhi sikap pengguna media sosial terhadap kampanye pada dua kategori kelompok, yaitu pengguna media sosial yang belum pernah (151 sampel) dan pengguna media sosial yang pernah melihat kampanye Stop Illegal Fishing di media sosial, (La Moriansyah, 2015).

\section{Zona Ekonomi Eksklusif Indonesia \\ Definisi ZEE terdapat dalam} ketentuan Pasal 55 dan 57 Konvensi Hukum Laut tahun 1982 sebagai suatu wilayah di luar dan berdampingan dengan laut territorial, yang tidak melebihi jarak 200 mil laut dari garis pangkal dari mana lebar laut territorial diukur(yaitu,200 mil laut yang tidak diukur dari batas laut terluar dari laut territorial).

Menurut jurnal "Prinsip efisiensi dalam peradilan tindak pidana perikanan" menjelaskan fokus perhatian adalah berkenaan 
dengan kemungkinan munculnya ketidakefisienan (inefficiency) dari pembentukan, penerapan maupun penegakan hukum (enforcement) dari peraturan perundangundangan, yaitu terhadap tindak pidana bidang perikanan, yang mencakup penyidikan, penuntutan, dan pemeriksaan di sidang pengadilan terhadap limpahan perkara pidana perikanan yang diajukan oleh kejaksaan ke pengadilan tentang adanya tindak pidana bidang perikanan kapal ikan asing yang melakukan illegal fishing dengan locus di zona ekonomi eksklusif indonesia (zeei) dapat terselesaikan proses pengadilan memenuhi prinsip efisiensi yaitu cepat, cermat, dan berbiaya ringan.(Abdullah,2014)

$$
\text { Definisi mengenai Zona }
$$

Ekonomi Eksklusif Indonesia terdapat dalam ketentuan Pasal 2 UU No. 5 Tahun 1983 yaitu:"Zona Ekonomi Eksklusif Indonesia adalah jalur di luar dan berbatasan dengan laut wilayah Indonesia sebagaimana yang ditetapkan berdasarkan Undang-Undang yang berlaku tentang perairan Indonesia yang meliputi dasar laut, tanah di bawahnya dan air di atasnya dengan batas terluar 200 (dua ratus) mil laut diukur dari garis pangkal laut wilayahIndonesia."

\section{Ekspor Ikan Tongkol/Tuna di Indonesia}

Adapun data ekspor ikan tongkol atau tuna di Indonesia dapat dijelaskan sebagai berikut:

Tabel 1

Ekspor Ikan Tongkol/Tuna Menurut Negara Tujuan Utama, 2012-2015

(Berat Bersih: ton)

\begin{tabular}{|c|c|c|c|c|}
\hline $\begin{array}{l}\text { Negara } \\
\text { Tujuan }\end{array}$ & 2012 & 2013 & 2014 & 2015 \\
\hline Jepang & 29,236 & 33,116 & 25,118 & 26,167 \\
\hline Hongkong & 138 & 217 & 75 & 110 \\
\hline Taiwan & 255 & 351 & 360 & 125 \\
\hline Thailand & 42,974 & 44,777 & 47,920 & 34,868 \\
\hline Singapura & 360 & 572 & 658.2 & 441 \\
\hline Vietnam & 3,320 & 2,678 & 2,234 & 1,165 \\
\hline $\begin{array}{l}\text { Australia } \\
\text { Amerika }\end{array}$ & 91.5 & 127 & 118 & 70 \\
\hline Serikat & 4,515 & 4,199 & 2,359 & 1,477 \\
\hline Belanda & 156 & 74 & 946 & 41 \\
\hline Belgia & 10 & 209 & 41 & 25 \\
\hline Lainnya & 24,669 & 26,022 & 21,278 & 12,971 \\
\hline Jumlah & 105,727 & 112,347 & 101,111 & 77,465 \\
\hline Sumber: & $\begin{array}{l}\text { Berdasarkan } \\
\text { penggunaan } \\
\text { menggantikan } \\
\text { dokumen kepa } \\
\text { (PEB dan P } \\
\text { Statistik Indon }\end{array}$ & $\begin{array}{l}\text { Keppres } \\
\text { kata } \\
\text { kata } \\
\text { abeanan } D \\
\text { IB). Dik } \\
\text { tesia }\end{array}$ & $\begin{array}{l}\text { No.12/2014 } \\
\text { Tiongkok } \\
\text { Cina. Diolal } \\
\text { Ditjen Bea dar } \\
\text { utip dari P }\end{array}$ & $\begin{array}{r}\text { tentang } \\
\text { untuk } \\
\text { h dari } \\
\text { n Cukai } \\
\text { ublikasi }\end{array}$ \\
\hline
\end{tabular}

Dari data tabel 1 diatas dapat disimpulkan bahwa 4 negara tujuan ekspor selalu mendominasi Ikan Tongkol/Tuna negara Thailand, jepang,amerika serikat dan Vietnam. Untuk Negara hongkong, Taiwan,singapura,Australia,belanda, belgiadan lainnya menempati nilai ekspor Komoditas ekspor Ikan Tongkol/Tuna yang relatif kecil.

Namun, produksi yang besar tidak diimbangi oleh konsumsi dan permintaan di dalam negeri.Sebanyak $70 \%$ produksi ikan tuna Indonesia justru diekspor ke Thailand, vitnam, Tiongkok, Jepang, Amerika Serikat, dan Uni Eropa.

Potensi konsumsi ikan tuna di Indonesia cukup besar hingga kini angka konsumsi ikan tuna segar masih minim. Masyarakat Indonesia lebih suka mengkonsumsi ikan tuna kalengan dibandingkan ikan tuna segar. 
Komoditas ekspor Ikan Tongkol/Tuna negara Thailand dapat di lihat mengalami trand kenaikan namun pada tahun 2015 mengalami penurunan yang dibarengi dengan penurunan agregat. Sedangkan Komoditas ekspor Ikan Tongkol/Tuna Negara jepang secara histori selalu menempati urutan teratas akan permintaan ikan tongkol atau tuna. Baru setelah beberapa tahun ini komoditas ikan tongkol atau tuna dikalahkan oleh Thailand.

\section{Tanpa Ikan Indonesia, Ekspor Hasil Laut Thailand Terjun Bebas}

Pemberantasan pencurian ikan di perairan Indonesia berdampak langsung pada anjloknya ekspor perikanan Thailand yang berimbas kepada produk domestik bruto (PDB) negara tersebut.

Data National Economic and Social Development Board (NESDB) Thailand mengungkapkan kontribusi sektor perikanan terhadap PDB Thailand mengalami penurunan drastis. Kontribusi rata-rata sektor perikanan terhadap GDP Thailand selama ini tercatat sebesar 1,6 persen, sedangkan di kuartal III 2015 kontribusinya minus 3,1 persen.

\section{Sementara Kementerian} Kelautan dan Perikanan (KKP) mencatat pada 2013 sampai kuartal II 2014, industri perikanan Thailand mengalami penurunan. Kemudian mulai membaik dari pertengahan kuartal III sampai pertengahan kuartal IV.

Namun sejak itu, industri perikanan Thailand terus menurun hingga saat ini.Salah satu penyebab utamanya adalah kebijakan Menteri Kelautan dan Perikanan Susi Pudjiastuti yang mulai memberantas kapal penangkap ikan ilegal dan moratorium bekas kapal asing di kuartal IV 2014.
"Hal ini menunjukkan
ketergantungan perikanan Thailand dengan pasokan ikan dari Indonesia.Selama setahun terakhir pemberantasan illegal fishing, sejumlah kapal berbendera Thailand berhasil ditangkap saat mengambil ikan di perairan Indonesia," kata Susi, dikutip Rabu (16/12).

Selain sebagai kejahatan perikanan, Susi juga ingin mendorong Illegal, Unreported, and Unregulated (IUU) Fishing sebagai permasalahan global dan memiliki sifat kejahatan transnasional. Salah satu alasan Susi ingin mengecam lebih luas penangkapan pencuri ikan karena kejahatan ini kerap memfasilitasi pelanggaran lainnya, seperti perdagangan satwa liar, perdagangan senjata, penyelundupan narkoba dan perbudakan.

\section{KESIMPULAN}

1. Komoditas ekspor Ikan Tongkol/Tuna negara Thailand dapat di lihat mengalami trand kenaikan namun pada tahun 2015 mengalami penurunan yang dibarengi dengan penurunan agregat. Sedangkan Komoditas ekspor Ikan Tongkol/Tuna Negara jepang secara histori selalu menempati urutan teratas akan permintaan ikan tongkol atau tuna. Baru setelah beberapa tahun ini komoditas ikan tongkol atau tuna dikalahkan oleh Thailand.

2. industri perikanan Thailand terus menurun hingga saat ini.Salah satu penyebab utamanya adalah kebijakan Menteri Kelautan dan Perikanan Susi Pudjiastuti yang mulai memberantas kapal 
penangkap ikan ilegal dan moratorium bekas kapal asing di kuartal IV 2014.

3. Selain sebagai kejahatan perikanan, Susi juga ingin mendorong Illegal, Unreported, and Unregulated (IUU) Fishing sebagai permasalahan global dan memiliki sifat kejahatan transnasional. Salah satu alasan Susi ingin mengecam lebih luas penangkapan pencuri ikan karena kejahatan ini kerap memfasilitasi pelanggaran lainnya, seperti perdagangan satwa liar, perdagangan senjata, penyelundupan narkoba dan perbudakan.

\section{DAFTAR PUSTAKA}

Abdullah, sayidin. 2014. Prinsip efisiensi dalam peradilan tindak pidana perikanan. Fiat justisia jurnal ilmu hukum volume 8 no. 3, juli-september 2014. Law Firm Sayidin, Sitompul And Partners Jakarta.

Koers, Albert W. diterjemahkan oleh Rudi M. Rizal dan Wahyuni Bahar, 1991, Konvensi Perserikatan Bangsa-Bangsa Tentang Hukum Laut, Gadjah Mada University Press, Yogyakarta.

Likadja, Frans E., 1988, Hukum Laut dan Undang-Undang Perikanan, Ghalia Indonesia, Jakarta.

Starke, J.G., 2008, Pengantar Hukum Internasional, Edisi Kesepuluh, Sinar Grafika, Jakarta.

http://news.detik.com/read/2009/10/ 09/080806/1218292/471/illega l-fishing-kejahatan

transnasional-yang-dilupakan, diaksespada tanggal 12

Februari 2014.

http://mukhtar.api.blogspot.co $\mathrm{m} / 2011 / 05 /$ illegal-fishing-diindonesia.html, diakses pada tanggal 12 Februari 2014.

http://ppnpemangkat.blogspot.com/ 2010/01/apakah-ilegalfishing.html, diakses pada tanggal 2 Mei 2014.

http://infopublik.kominfo.go.id/rea d/812/kkp-tegaskanpenangkapan-dua-kapal-ikanberbendera-malaysia-sudahsesuai-prosedur.html, diakses pada tanggal 18 Mei 2014.

Undang-Undang No. 31 Tahun 2004 tentang Perikanan.

Keputusan Menteri No. KEP/50/MEN/2012 tentang Rencana Aksi Nasional Pencegahan dan Penanggulangan IUU Fishing.

Saut Tampubolon, Kabid Subdit Sumber Daya Ikan ZEE dan Laut Lepas Kementerian Kelautan dan Perikanan, 2014, Power Point RFMO dan Resolusinya dalam Pengelolaan Tuna di ZEEI dan Laut Lepas, Jakarta.

https://finance.detik.com/ekonomibisnis/2631579/ini-alasantuna-paling-diburu-paramaling-ikan-di-lautindonesia

http://www.cnnindonesia.com/ekon omi/20151216125914-9298589/tanpa-ikan-indonesia- 
ekspor-hasil-laut-thailand-

terjun-bebas/

Le Gallic, Bertrand. 2007. Analysis

The Use Of Trade Measures Against Illicit Fishing:

Economic And Legal

Considerations. Ecological economics 64 (2008) 858866.

Centre De Droit et d'Economie de la Mer (CEDEM), AMURE Research Group, University of Western Brittany (UBO), 12, rue de Kergoat, CS 93837, 29238 Brest Cedex 3, France.

La Moriansyah. 2015." Motivasi, Sikap, dan Intensi Pengguna Media Sosial Pada Kampanye Stop Illegal Fishing". Tersedia Online Http://Journal.Ipb.Ac.Id/Inde x.Php/Jmagr. Nomor Doi: 10.17358/Jma.13.3.192. 